\title{
Role of benzothiadiazole and peak performance nutrient on inducing resistance in Citrus aurantifolia against Xanthomonas axonopodis pv. citri
}

\author{
Shahran Ahmed Nayem ${ }^{1}$, Md. Sahadat Ali ${ }^{2}$, Md. Belal Hossain $^{1^{*}}$, Abul Hasnat Solaiman $^{3}$, M. Salahuddin \\ M. Chowdhury ${ }^{1}$
}

${ }^{1}$ Department of Plant Pathology, Sher-e-Bangla Agricultural University, Bangladesh
${ }^{2}$ Horticultural Science, Technical University of Munich, Freising 85354, Germany
${ }^{3}$ Department of Horticulture, Sher-e-Bangla Agricultural University, Bangladesh

*Corresponding author: mbhossainsau@gmail.com

Abstract

Citrus canker caused by Xanthomonas axonopodis pv.citri (Xac) is a pernicious disease that retards quality citrus production. In this study, we investigated the individual and combined competence of Benzothiadiazole (BTH), Peak Performance Nutrients (PPN) and Riboflavin (Rib) to mitigate the progress of canker disease. Lime seedlings of BARI Lebu-2 inoculated with Xac bacteria were used in the study. There were three individual and three combined treatments such as PPN, BTH, Rib and (PPN+BTH), (PPN+Rib), (PPN+BTH+Rib) wherein the concentrations were $0.4 \%(P P N), 1 \mathrm{mM}(\mathrm{BTH})$ and $2 \mathrm{mM}(\mathrm{Rib})$. Water treated plants were used as a control. Plants were sprayed with treatments after ten days of interval and for the combined treatment, the second and third chemical was sprayed on the following day after application of the first chemicals. The result divulged that, (PPN+BTH) and (PPN+BTH+Rib) showed the best performance to attenuate disease severity (DS) and lesion diameter (LD) accompanied by an augmentation of latent period. In addition, they inclined Total Phenolic Compound (TPC), Soluble Protein (SP) and Phenylalanine ammonia lyase (PAL) activity within the plants. Besides, plants treated with PPN singly or in combination with BTH and Rib showed higher accumulation of nutrient minerals such as $N, P, K, C a, F e$ and $\mathrm{Zn}$ than PPN non-treated plants. Based on the findings, we suggest that application of $(P P N+B T H)(0.4 \%+1 \mathrm{mM})$ and $(P P N+B T H+R i b)(0.4 \%+1 \mathrm{mM}+2 \mathrm{mM})$ is effective on inducing resistance in the citrus plant against Xac.

Keywords: Citrus canker; Disease severity; Induce resistance; Riboflavin.

Abbreviations: BTH_Bezothiadiazole; DAI_Days after inoculation; DS_Disease severity; LD_Lesion diameter; PAL_Phenylalanine ammonia lyase; PPN_Peak Performance Nutrients; Rib_Riboflavin; SP_Soluble Protein; TPC_Total Phenolic Compound.

\section{Introduction}

Induced resistance (IR) is a harmless, non-toxic and ecofriendly management approach wherein, plant's innate defenses are potentiated against subsequent biotic challenges by specific elicitors thorough modulation of physiological process. Two distinct form of IR is Systemic Acquired Resistance (SAR) and Induced Systemic Resistance (ISR) which is differentiated on the basis of regulatory pathway and nature of elicitors (Yan et al., 2002). Elicitors are natural or synthetic compounds that activate chemical defense in the plant (Garcia-Brugger et al., 2006). However, IR against citrus canker through the application of different elicitors was investigated previously (Wang and Liu, 2012; Li and Wang, 2013; Nayem et al., 2017). Quality citrus production is being hindered by Xanthomonas axonopodis pv.citri that is influencing world citrus industry. Thereby, management of this disease is a major concern for the citrus growers. Chemicals were proved less effective against the disease as well as noxious for the environment (Graham and Leite, 2004). Therefore, concentration is focused on the propitious method of disease management such as induce resistance that will be friendly for the environment as well as for mankind (Oliveira et al., 2013; Hasabi et al., 2014). It has been established that IR is provoked by elicitors such as Benzothiadiazole (BTH), Riboflavin (Rib) and Peak Performance Nutrients (PPN) against several plant diseases (Zhu et al., 2003; Taheri and Hofte, 2007; Liu et al., 2010). BTH is the functional analog of salicylic acid which induced defense against plant disease through morphological and physiological modulation (Hukkanen et al., 2007). However, it does not depend on salicylic acid/jasmonic acid signaling pathway and can activate a number of SAR related gene independently as a secondary messenger analog (Benhamous and Belanger, 1998). In Cucumber BTH increased huge accumulation of phenolic compound (Benhamous and Belanger, 1998). It was involved in the accumulation of total phenolic compounds activation of key enzymes and PR protein (Friedrich et al., 1996). Riboflavin (Vitamin $B_{2}$ ) regulates the physiological process of plants, animals and microbes as a co-enzyme by involving antioxidation (Goodman et al., 1986). Rib play a vital role in plant-microbe interaction by inducing enzymatic activity such as peroxidase, phenylalanine ammonia-lyase, 
polyphenol oxidase and accumulation of flavonoids, phenolics. The Rib has been suggested as a dynamic elicitor for inducing resistance against many plant diseases (Dong and Bear, 2000; Li et al., 2012). Again, Peak Performance Nutrients (PPN) is a liquid formulation which contains various botanicals including vegetable oil extracts, plant extracts and seed extracts etc. It improves morphological and physiological feature and provides resistance along with other chemicals in plants through the supply of additional nutrient material (Sayed, 2015). It is eco-friendly, nonresidue, non-toxic and increases drought resistance, prevents virus attack. Above information supports that elicitors like BTH, Rib and PPN can create a favorable condition for the plant to resist pathogen by modulating physiological and molecular process. In this study, we aimed to understand how exogenous application of these elicitors singly or in combination mitigates citrus canker disease.

\section{Results}

\section{Culture and confirmation of causal organism}

On the basis of biochemical and pathogenicity test the collected pathogenic bacterium was confirmed as Xanthomonas axonopodis PV. Citri. The bacterium was rodshaped with rounded ends, cells appeared singly and also in pairs, gram-negative (red color) and capsulated under the compound microscope at 100 times magnification with oil immersion. The bacterium produced a mucoid thread in $\mathrm{KOH}$ solution when lifted with the loop. Again, it showed catalase activity; bubbles were formed after adding $3 \% \quad \mathrm{H}_{2} \mathrm{O}_{2}$. Besides, starch was hydrolyzed, esterase enzyme was produced in tween 80 lipolysis test, milk was proteolyzed, gelatin was liquefied, citrate was utilized. In addition, it formed dark purple color on oxidase disk, showed $\beta$ glycosidase activity in esculin hydrolysis test and the findings are summarized in Table 1 . Furthermore, the bacterium showed a positive result in pathogenicity test.

\section{Development of citrus canker disease in Xac inoculated} plants after application of treatments

In the treatments, (PPN+BTH), (PPN+BTH+Rib), BTH and (PPN+Rib) significantly mitigated canker development compared to control particularly by the former two than the latter two. Significant variation in latent period was recorded at different treatments (Fig $1 \mathrm{~A}$ ). Xac took 11.46 days to express symptom in (PPN+BTH) and (PPN+BTH+Rib) treated plants while 10.6 and 10.8 days in BTH and (PPN+Rib) treated plants, whereas in control, PPN and Rib treated plants it took 8 days to express symptom. However, at 15 Days after inoculation (DAI), the treatments differed greatly in disease severity (DS), 3.93 and $3.80 \%$ for (PPN+BTH) and (PPN+BTH+Rib) respectively while 10.66 and $10.93 \%$ for BTH and (PPN+Rib) respectively, whereas control, PPN and Rib had a DS of 20.40, 20 and $19.60 \%$ (Table 2, Fig 2). DS at different treatments increased by degrees prior to the end of experiment but (PPN+BTH) and (PPN+BTH+Rib) treated plants had the lowest and statistically similar DS (11\% and $10.93 \%)$ compare to control (33.93\%) at $30 \mathrm{DAl}$ and (15.66 $\%$ and $15.33 \%$ ) compared to control (49.33\%) at 45 DAI. Moderate DS (20.93\% and 28.66\%) were recorded at BTH treated plants along with (PPN+Rib) $(21.93 \%$ and $30.33 \%)$ treated plants at $30 \mathrm{DAl}$ and $45 \mathrm{DAl}$. Conversely, PPN and Rib treated plants showed the highest and statistically similar DS with control at $30 \mathrm{DAl}$ and $45 \mathrm{DAl}$. Again, (PPN+BTH+Rib) and (PPN+BTH) showed the highest average \% reduction of disease over control (71.00 and $70.49 \%$ ) while BTH and (PPN+Rib) had moderate (41.87\% and $39.04 \%$ ) average \% reduction of disease over control (Table 2). Furthermore, lesion diameter (LD) varied significantly among (PPN+BTH+Rib) $\left(3.93 \mathrm{~mm}^{2}\right),(\mathrm{PPN}+\mathrm{BTH})\left(4 \mathrm{~mm}^{2}\right),(\mathrm{PPN}+\mathrm{Rib})$ $\left(5.87 \mathrm{~mm}^{2}\right)$, BTH $\left(5.66 \mathrm{~mm}^{2}\right), \operatorname{PPN}\left(7.33 \mathrm{~mm}^{2}\right), \operatorname{Rib}(7.27$ $\mathrm{mm}^{2}$ ) and Control $\left(7.13 \mathrm{~mm}^{2}\right.$ ) (Fig $1 \mathrm{~B}$ ). The results summarized that application of BTH individually or in combination with PPN could mitigate DS of citrus canker.

\section{Amount of total phenolic compounds on leaves at different} treatments

Total phenolic compounds were investigated in order to perceive that whether the applied chemicals could increase the accumulation of TPC in a plant cell or not. The accumulation of TPC was notably significant in (PPN+BTH+Rib), (PPN+BTH), BTH and (PPN+Rib) treated plants than control at $15 \mathrm{DAl}, 30 \mathrm{DAl}$ and $45 \mathrm{DAl}$ respectively (Fig $3 \mathrm{~A}$ ). In the treatments, (PPN+BTH+Rib) treated plants had threefold highest TPC content $\left(13.23 \mathrm{mg} \mathrm{g}^{-1}\right)$ at $45 \mathrm{DAl}$ compared with control $\left(4.23 \mathrm{mg} \mathrm{g}^{-1}\right)$. Besides, (PPN+BTH), BTH and (PPN+Rib) treated plants had a moderate and statistically significant TPC content $\left(11.47 \mathrm{mg} \mathrm{g}^{-1}, 9.7 \mathrm{mg} \mathrm{g}^{-1}\right.$ and $8.43 \mathrm{mg} \mathrm{g}^{-1}$ ), whereas PPN and Rib showed the lowest and statistically similar TPC accumulation $\left(4.26 \mathrm{mg} \mathrm{g}^{-1}\right.$ and $4.06 \mathrm{mg} \mathrm{g}^{-1}$ ) with control. Similar results pattern was found at $15 \mathrm{DAl}$ and $30 \mathrm{DAl}$. TPC of (PPN+BTH+Rib), (PPN+BTH), $\mathrm{BTH}$ and (PPN+Rib) treated plants showed a continuous increase from 15 DAl to 45 DAl whereas, Control, PPN, and Rib treated plants remained stable. Hence, the results indicating that application of BTH individually or in combination with PPN augmented TPC in plant leaf that could influence plant resistance.

\section{Amount of soluble protein on leaves at different treatments}

The result in Fig $3 \mathrm{~B}$ showed that content of $\mathrm{SP}$ in (PPN+BTH+Rib), (PPN+BTH), BTH and (PPN+Rib) treated plants were statistically similar and the highest $(21.13 \mathrm{mg} \mathrm{g}$ $\left.1,23.12 \mathrm{mg} \mathrm{g}^{-1}, 24.33 \mathrm{mg} \mathrm{g}^{-1}\right),\left(21.63 \mathrm{mg} \mathrm{g}^{-1}, 23.03 \mathrm{mg} \mathrm{g}^{-1}\right.$, $\left.25.4 \mathrm{mg} \mathrm{g}^{-1}\right),\left(20.56 \mathrm{mg} \mathrm{g}^{-1}, 22.2 \mathrm{mg} \mathrm{g}^{-1}, 24.67 \mathrm{mg} \mathrm{g}^{-1}\right)$ and $\left(20.93 \mathrm{mg} \mathrm{g}^{-1}, 20.86 \mathrm{mg} \mathrm{g}^{-1}, 23.03 \mathrm{mg} \mathrm{g}^{-1}\right)$ than control (11.15 $\mathrm{mg} \mathrm{g}^{-1}, 12.86 \mathrm{mg} \mathrm{g}^{-1}$ and $\left.13.83 \mathrm{mg} \mathrm{g}^{-1}\right)$ at 15,30 and 45 DAl respectively, whereas PPN and Rib treated plants showed statistically similar SP content with control at 15,30 and 45 DAI. SP of (PPN+BTH+Rib), (PPN+BTH), BTH and (PPN+Rib) treated plants showed continuous increase from $15 \mathrm{DAl}$ to 45 DAl whereas, Control, PPN and Rib treated plants remained stable.

\section{PAL activity of inoculated leaf at different treatment}

PAL activity at $15 \mathrm{DAl}, 30 \mathrm{DAl}$ and $45 \mathrm{DAl}$ were investigated since it is an important enzyme involved in plant resistance. PAL activity was higher in (PPN+BTH+Rib), (PPN+BTH), BTH 
Table 1. Biochemical characteristics of pathogenic bacteria of citrus canker.

\begin{tabular}{ll}
\hline Biochemical tests & Results \\
\hline KOH solubility test & Positive \\
Catalase test & Positive \\
Gelatine liquefaction test & Positive \\
Oxidase test & Negative \\
Starch hydrolysis test & Positive \\
Aesculin hydrolysis & Positive \\
Citrate utilization test & Positive \\
Milk protolysis & Positive \\
Tween 80 lipolysis & Positive \\
\hline
\end{tabular}
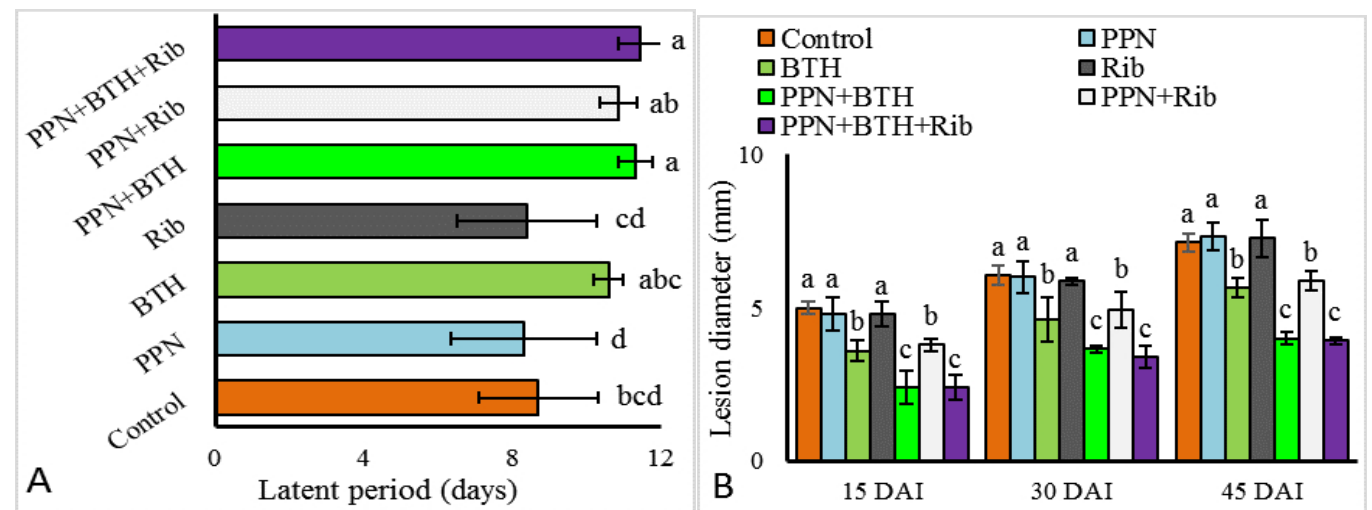

Fig 1. Latent period $(A)$ and Lesion diameter $(B)$ of citrus canker at different treatments. Different lowercase letters above the bar indicate significant at $\mathrm{P}<0.01$.

Table 2. Effect of some selected elicitors on Disease severity of citrus canker.

\begin{tabular}{|c|c|c|c|c|c|}
\hline \multirow[t]{2}{*}{ Treatments } & \multicolumn{3}{|c|}{$\%$ Disease severity (DS) } & \multirow[t]{2}{*}{ Average \% DS } & \multirow{2}{*}{$\begin{array}{l}\text { Average } \% \text { reduction } \\
\text { over control }\end{array}$} \\
\hline & $15 \mathrm{DAl}$ & $30 \mathrm{DAl}$ & $45 \mathrm{DAl}$ & & \\
\hline Control & $20.40 \mathrm{a}$ & 33.93 a & 49.33 a & 34.55 & 0 \\
\hline PPN & $20.00 \mathrm{a}$ & $32.66 \mathrm{ab}$ & $48.33 \mathrm{a}$ & 33.66 & 2.57 \\
\hline BTH & $10.66 \mathrm{~b}$ & $20.93 c$ & $28.66 \mathrm{~b}$ & 20.08 & 41.87 \\
\hline Rib & $19.60 \mathrm{a}$ & $31.93 b$ & $47.33 \mathrm{a}$ & 32.95 & 4.63 \\
\hline $\mathrm{PPN}+\mathrm{BTH}$ & $3.93 c$ & $11.00 \mathrm{~d}$ & $15.66 \mathrm{c}$ & 10.19 & 70.49 \\
\hline PPN+Rib & $10.93 \mathrm{~b}$ & $21.93 \mathrm{c}$ & $30.33 \mathrm{~b}$ & 21.06 & 39.04 \\
\hline $\mathrm{PPN}+\mathrm{BTH}+\mathrm{Rib}$ & $3.80 c$ & $10.93 \mathrm{~d}$ & $15.33 \mathrm{c}$ & 10.02 & 71.00 \\
\hline CV (\%) & 6.10 & 3.37 & 5.99 & & \\
\hline S. E & 0.63 & 0.64 & 1.64 & & \\
\hline LSD (0.05) & 1.36 & 1.37 & 3.52 & & \\
\hline Level of significance & $* *$ & $* *$ & $* *$ & & \\
\hline
\end{tabular}

Fig 2. Disease symptoms of citrus canker at 45 DAl (A) control (B) PPN+BTH+Rib treatment. 
Table 3. Amount of nutrient minerals in leaf at different treatments at $45 \mathrm{DAl}$.

\begin{tabular}{|c|c|c|c|c|c|c|}
\hline Treatments & $\mathrm{N}(\%)$ & $\mathrm{K}\left(\mathrm{mg} \mathrm{g}^{-1}\right)$ & $\mathrm{P}\left(\mathrm{mg} \mathrm{g}^{-1}\right)$ & $\mathrm{Ca}\left(\mathrm{mg} \mathrm{g}^{-1}\right)$ & Fe $\left(\mathrm{mg} \mathrm{g}^{-1}\right)$ & $\mathrm{Zn}\left(\mathrm{mg} \mathrm{g}^{-1}\right)$ \\
\hline Control & $1.54 \mathrm{c}$ & $5.83 \mathrm{c}$ & $0.96 \mathrm{c}$ & $4.00 \mathrm{c}$ & $0.11 \mathrm{c}$ & $0.01 \mathrm{~d}$ \\
\hline PPN & $1.96 \mathrm{~b}$ & $11.50 \mathrm{~b}$ & $4.16 \mathrm{~b}$ & $7.83 \mathrm{~b}$ & $0.25 b c$ & $0.08 \mathrm{~cd}$ \\
\hline BTH & $1.54 \mathrm{c}$ & $7.83 \mathrm{c}$ & $1.31 \mathrm{c}$ & $4.00 \mathrm{c}$ & $0.06 \mathrm{c}$ & $0.02 \mathrm{~cd}$ \\
\hline Rib & $1.56 \mathrm{c}$ & $7.50 \mathrm{c}$ & $2.16 \mathrm{c}$ & $4.33 \mathrm{c}$ & $0.10 \mathrm{c}$ & $0.02 \mathrm{~cd}$ \\
\hline $\mathrm{PPN}+\mathrm{BTH}$ & $2.85 \mathrm{a}$ & $15.66 \mathrm{a}$ & $7.16 \mathrm{a}$ & $12.33 \mathrm{a}$ & $0.81 \mathrm{a}$ & $0.20 \mathrm{a}$ \\
\hline PPN+Rib & $2.12 \mathrm{~b}$ & $11.00 \mathrm{~b}$ & $4.16 \mathrm{~b}$ & $7.33 \mathrm{~b}$ & $0.31 \mathrm{bc}$ & $0.09 \mathrm{bc}$ \\
\hline $\mathrm{PPN}+\mathrm{BTH}+\mathrm{Rib}$ & $2.96 \mathrm{a}$ & $15.50 \mathrm{a}$ & $6.16 \mathrm{a}$ & $12.83 \mathrm{a}$ & $0.66 \mathrm{ab}$ & $0.16 a b$ \\
\hline CV (\%) & 5.54 & 13.69 & 19.21 & 21.11 & 76.42 & 52.57 \\
\hline S. E & 0.09 & 1.19 & 0.58 & 1.29 & 0.20 & 0.03 \\
\hline LSD (0.05) & 0.20 & 2.56 & 1.25 & 2.78 & 0.44 & 0.07 \\
\hline Level of significance & $* *$ & $* *$ & $* *$ & $* *$ & $* *$ & $* *$ \\
\hline
\end{tabular}

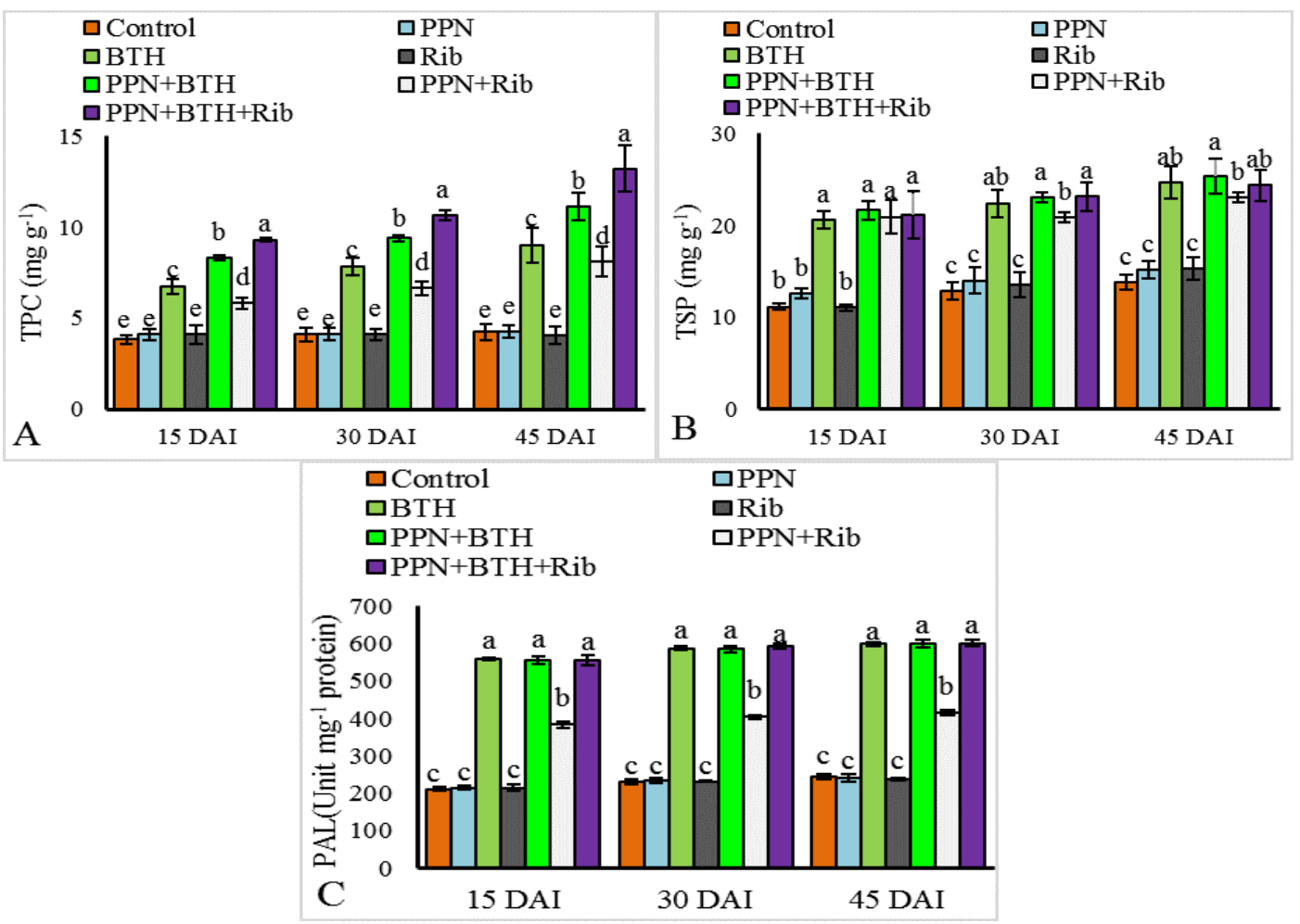

Fig 3. Total Phenol content (A), Soluble protein (B) and PAL activity (C) at different treatment in Xac inoculated plants at 15,30 and 45 DAI. Different lowercase letters above the bar indicate significant at $P<0.01$.

and (PPN+Rib) treated plants than control at15 DAl, $30 \mathrm{DAl}$ and 45 DAl respectively (Fig 3 C). (PPN+BTH+Rib), (PPN+BTH), BTH treated plants had the highest and statistical similar PAL activity while (PPN+Rib) had moderate PAL activity. Nevertheless, PPN and Rib treated plants showed the lowest and statistically similar PAL activity with control.

\section{Accumulation of nutrients minerals in leaf at different treatments}

Nutrient minerals such as $\mathrm{N}, \mathrm{P}, \mathrm{K}, \mathrm{Ca}, \mathrm{Fe}$ and $\mathrm{Zn}$ were examined to perceive whether applied elicitors could accumulate them in leaf not. Accumulation of these minerals was notably significant in (PPN+BTH+Rib), (PPN+BTH), BTH and (PPN+Rib) treated plants than control at $45 \mathrm{DAl}$ (Table 3). (PPN+BTH+Rib) and (PPN+BTH) treated plants showed the highest accumulation of $\mathrm{N}, \mathrm{P}, \mathrm{K}, \mathrm{Ca}, \mathrm{Fe}$ and $\mathrm{Zn}(2.96 \%$,
$6.16 \mathrm{mg} \mathrm{g}-1,15.50 \mathrm{mg} \mathrm{g}-1,12.83 \mathrm{mg} \mathrm{g}-1,0.66 \mathrm{mg} \mathrm{g}-1$ and $0.16 \mathrm{mg} \mathrm{g}-1)$ and $(2.85 \%, 7.16 \mathrm{mg} \mathrm{g}-1,15.66 \mathrm{mg} \mathrm{g}-1,12.33$ $\mathrm{mg} \mathrm{g}-1,0.81 \mathrm{mg} \mathrm{g}-1$ and $0.20 \mathrm{mg} \mathrm{g}-1$ ) respectively while PPN and (PPN+Rib) treated plants showed moderate accumulation (1.96 \%, $4.16 \mathrm{mg}$ g-1, $11.50 \mathrm{mg}$ g- $1,7.88 \mathrm{mg}$ g$1,0.25 \mathrm{mg} \mathrm{g}-1$ and $0.08 \mathrm{mg} \mathrm{g}-1)$ and $(2.12 \%, 4.16 \mathrm{mg} \mathrm{g}-1,11$ $\mathrm{mg}$ g-1, $7.33 \mathrm{mg} \mathrm{g}-1,0.31 \mathrm{mg} \mathrm{g}-1$ and $0.09 \mathrm{mg}$ g-1) respectively compared to control. However, BTH and Rib treated plants showed the lowest accumulation of nutrient minerals. The result indicates that nutrients accumulation was higher in the treatments which contained PPN singly or in combination.

\section{Discussion}

Proficiency of BTH and Rib to attenuate plant disease through performing physiological role has been well established (Boubakri et al., 2013; Li et al., 2016). In our 
study, application of treatments (PPN+BTH+Rib) and (PPN+BTH) for five weeks showed the highest mitigation of canker disease development and application of BTH, (PPN+Rib) showed moderate mitigation which was undoubtedly manifested by the lower disease severity and lesion diameter that agrees with previous investigations (Scarponi et al., 2001; Faoro et al., 2008; Li et al., 2012; Sayed, 2015). Besides, Canker symptoms were onset earlier in control, PPN and Rib treated plants and later on (PPN+BTH+Rib), (PPN+BTH), (PPN+Rib) and BTH treated plants which provide evidence that BTH and the combined treatments slowed the infection process of pathogen and led to a belated occurrence of canker disease whereas, individual application of PPN and Rib were in vain. Next, in our experiment we found higher PAL activity in (PPN+BTH+Rib), (PPN+BTH), BTH and (PPN+Rib) treated plants than control particularly in the former three treatments, in agreement with an earlier study (Stadnikard and Buchenauer, 2000; Li et al., 2012). It has been revealed that PAL synthesized secondary phenolic compounds, lignin and isoflavones which led to the restriction of pathogen multiplication within plant cell (Gurr and Rustan, 2005). Amusingly, we observed that (PPN+BTH+Rib), (PPN+BTH), $\mathrm{BTH}$ and (PPN+Rib) treated plants had higher TPC than control especially in the former three treatments that could be influenced by PAL although other chances could exist. It is found that increase of TPC alleviated DS (Liu et al., 2010; Maddox et al., 2010; Biswas et al., 2012). At the time of pathogen infection, hydrolyzing enzyme turned the cell wall bound inactive TPC into active TPC which retard pathogen growth. Again, our findings revealed that (PPN+BTH+Rib), (PPN+BTH), BTH and (PPN+Rib) treated plants showed higher accumulation of soluble protein than control, whereas PPN and Rib were similar with control in SP accumulation. It was revealed that, higher accumulation of SP provided induce resistance against the pathogen (Biswas et al., 2012). Besides, protein regulated Hypersensitive Response, activated SA signaling pathway, retard pathogen multiplication and act as a chaperone provider which fascinated plant resistance against the pathogen (Kovacs et al., 2009; Xu et al., 2012; Nagaraj et al., 2016). It is known that nutrient minerals had a multidimensional role in protein formation (Dordas, 2008). Alluringly, in our study, we found that accumulation of $\mathrm{N}, \mathrm{K}$ and $\mathrm{Zn}$ was higher in (PPN+BTH+Rib), (PPN+BTH), (PPN+Rib) and PPN treated plants. This higher amount of $\mathrm{N}, \mathrm{K}$ and $\mathrm{Zn}$ could be related to the accumulation of SP in leaf, in agreements with (Marschner, 1995; Dordas, 2008) although other possibilities could exist. In our findings though PPN treated plants showed higher accumulation of nutrient minerals, it had lower SP content but it was vice-versa in BTH treated plants. At this point, we could not explicate the explicit explanation for this happening. Again, our findings also indicated that accumulation of $\mathrm{P}, \mathrm{Ca}$ and $\mathrm{Fe}$ was higher in (PPN+BTH+Rib), (PPN+BTH), (PPN+Rib) and PPN treated plants. It has been proved that $\mathrm{P}, \mathrm{Ca}$ and $\mathrm{Fe}$ increased resistance in plants through regulation of plant metabolic function, membrane stability, and enzyme stimulation especially peroxidase (Dordas, 2008). In our study, PPN treatment showed higher accumulation of nutrient minerals but did not increase PAL activity, TPC, SP and ultimately was unable to reduce DS. On the other hand, (PPN+BTH+Rib), (PPN+BTH) and (PPN+Rib) treatments increased PAL, TPC and SP. This provides evidence that PPN alone did not play any role to mitigate DS but may provide extra benefit to BTH by supplying nutrients to fight against Xac.

Materials and methods

\section{Preparation of planting materials}

Vigorous, healthy, disease and insect free one-year-old lemon (Citrus limon L. Osbeck) seedlings of BARI Lebu-2 collected from Krishibid nursery Agargaon, Dhaka were used in this experiment. Collected lemon seedlings were potted (one plant/pot) in twenty-five-inch earthen pot and kept in shade for two days. Sterile loamy soil, sand and cow dung (2:1:1) were used as potting media. Potted seedlings were irrigated every day early in the morning with distilled water. No additional nutrient was supplied during the study period. The growth condition of net house was: relative humidity 60-73\% (night-day), temperature 26-32 OC (night-day), daylight 14 hour and UV in sunlight $734-810 \mathrm{~mW}-\mathrm{cm} 2$.

\section{Collection, confirmation and culture of causal organism}

The causal organism of citrus canker (Xanthomonas axonopodis pv. Citri) was collected from molecular plant pathology Lab, Dept. of Plant Pathology, Sher-e-Bangla Agricultural University and maintained in Nutrient Broth (NB) at $28{ }^{\circ} \mathrm{C}$ for 48 hours at shaker incubator and then cultured in Nutrient Agar (NA) media and subculture at onemonth interval following the method of Goszczynska and Serfontein (1998). The pathogen was confirmed as Xac by pathogenicity test and biochemical tests such as Potassium hydroxide $(3 \% \mathrm{KOH})$ test, Gram's staining reaction, Catalase test, Milk proteolysis test, Oxidase test, Starch hydrolysis test, Citrate utilization test, Esculin hydrolysis test, Tween 80 lipolysis test, Gelatin liquefaction test (Schaad, 1992).

\section{Preparation and application of treatment chemicals}

There were total 7 treatments with Control (water) which include three individual and three combined treatments such as PPN, BTH, Rib, (PPN+BTH), (PPN+Rib), (PPN+BTH+Rib). However, $0.14 \mathrm{~g}$ BTH, $0.8 \mathrm{~g}$ Rib and $4 \mathrm{~g}$ PPN were dissolved in one-liter sterile distilled water to get the concentration of $1 \mathrm{mM}, 2 \mathrm{mM}$ and $0.4 \%$ respectively. The chemicals were purchased from SIGMA ALDRICH, USA. Prepared elicitors solution was sprayed equally over the plants. Each plant was sprayed with $330 \mathrm{ml}$ solution approximately. Plants were sprayed with chemical solution after ten days of interval thus the treatments were maintained for seven weeks. The plants got total five spray solution. For the combined treatment, the second and third chemical was sprayed on the following day after application of the first chemicals. The concentration of chemicals was determined on the basis of preliminary investigation in the lab. For BTH, the concentration above $1 \mathrm{mM}$ gave the same result as $1 \mathrm{mM}$ but caused leaf defoliation whereas, the concentration below $1 \mathrm{mM}$ showed lower performance. For Rib, concentration above $1 \mathrm{mM}$ showed good performance. PPN did not show any performance against DS at any concentration and therefore the concentration $0.4 \%$ was fixed based on previous work (Sayed, 2015). 
Initially, bacteria were cultured in Nutrient broth $\left(30^{\circ} \mathrm{C}, 24\right.$ hours) before inoculation. Thereafter it was resuspended in sterile distilled water to a concentration of approximately $108 \mathrm{CFU} / \mathrm{ml}$ (OD: $0.5650 \mathrm{~nm}$ ). Then bacterial inoculums were injected into the lower surface of the healthy leaf with a syringe. Five leaves were inoculated from each plant and each leaf was inoculated with $0.5 \mathrm{ml}$ bacterial solution. The plants were inoculated with bacteria after seven days of the first spray. Data on latent period, lesion diameter, disease severity, TPC, SP, PAL were recorded at 15, 30 and 45 days after inoculation while mineral nutrients such as $\mathrm{N}, \mathrm{K}, \mathrm{P}, \mathrm{Ca}$, $\mathrm{Fe}$ and $\mathrm{Zn}$ were recorded at 45 days after inoculation. The disease severity was recorded by using the following scale developed by Rai and Mamatha (2005). The 0-5 grade disease severity scale was used for recording disease severity data. The grades were, $0=0 \%$ infection, $1=1 \%$ infection, $2=1-10 \%$ infection, $3=10-20 \%$ infection, $4=20$ $40 \%$ infection and $5=40-100 \%$ infection. The following formula was used to determine disease severity:

Percent Disease Index (PDI)= "Sum of individual disease rating" / ("Total number of leaf examinedx" @"maximum grade" ) "×100"

\section{Extraction and estimation of total phenolic compounds from leaves}

Total phenolic compounds of leaf were extracted by the following method of Biswas et al. (2012) with some modification. The evaluation was conducted at 15,30 and 45 DAI. Initially, $1 \mathrm{~g}$ fully dried ground leaf from each sample added with $80 \%$ ethanol $(1: 10 \mathrm{w} / \mathrm{v})$ was centrifuged at $10,000 \mathrm{rpm}$ for 30 minutes at room temperature. Distilled water was used as a blank. Afterward, $0.5 \mathrm{ml}$ of FCR was added and after three minutes, $2 \mathrm{ml}$ of $20 \% \mathrm{Na} 2 \mathrm{CO} 3$ solution was added to each tube. Then the tubes were heated in boiling water for $1 \mathrm{~min}$ and cooled at room temperature. Using Ultra Violet Visible (UV-VIS) spectrophotometer the absorbance at $650 \mathrm{~nm}$ against a blank (water) was measured and the standard curve was prepared using a different concentration of catechol. From the standard curve, phenols concentration was determined in the test sample and expressed as $\mathrm{mg} g-1$ of fresh sample materials.

\section{Extraction and estimation of soluble protein from leaves}

Soluble protein from leaf was extracted by the following method of Lawry et al. (1951) with slight modification. The evaluation was conducted at 15, 30 and 45 DAl. Initially, $1 \mathrm{~g}$ crushed citrus leaf with extracting buffer $(1: 5 \mathrm{~W} / \mathrm{V})$ was centrifuged at $15000 \mathrm{rpm}$ for $20 \mathrm{~min}$ at $4^{\circ} \mathrm{C}$. $1 \mathrm{ml}$ sample extract with $5 \mathrm{ml}$ alkaline copper solution was incubated at room temperature for 20 minutes. Then Folin-Ciocalteu reagent $(F C R, 0.5 \mathrm{ml}$ ) was mixed well and kept for 20 minutes. A $1 \mathrm{ml}$ distilled water was used as a blank. Finally, the absorbance at $660 \mathrm{~nm}$ was measured against blank using Ultra Violet Visible (UV-VIS) spectrophotometer and the standard curve was prepared using a different concentration of Bovine Serum Albumin. From the standard curve, the concentration of soluble protein was determined in the test sample and expressed as mg g-1 of fresh sample materials.
PAL activity was measured spectrophotometrically according to Yao and Tian (2005) described previously based on the production of trans-cinnamic acid. $0.5 \mathrm{~g}$ leaf from each sample was used for this assay. The evaluation was conducted at 15, 30 and 45 DAl. The PAL activity was defined as an increase in the trans-cinnamic acid produced by the amount of enzyme extract per $\mathrm{mg}$ of total protein per hour.

\section{Extraction of nutrient minerals from leaf}

\section{Estimation of $N$ from leaf}

$1 \mathrm{~g}$ dried leaf from each sample was taken and the amount of $\mathrm{N}$ in leaf was estimated by Kjeldahl flask method described previously by McKenzie and Wallace (1954). The evaluation was conducted at 45 DAI. The percent of $\mathrm{N}$ in the sample was calculated using the formula:" $\% \mathrm{~N}=(\mathrm{T}-\mathrm{B}) \times \mathrm{N} \times 1.4 "$ $\Lambda^{\prime} \mathrm{S}$ ", Where, $\mathrm{T}=$ titration value for sample $(\mathrm{ml}), \mathrm{B}=$ titration value for blank (ml), $\mathrm{N}=$ normality of $\mathrm{H} 2 \mathrm{SO} 4,1.4=$ conversion factor and $\mathrm{S}=$ weight of sample $(\mathrm{g})$.

\section{Extraction and Estimation of $P, K, \mathrm{Ca}, \mathrm{Fe}$ and $\mathrm{Zn}$ from leaf sample}

$\mathrm{P}, \mathrm{K}, \mathrm{Ca}, \mathrm{Fe}$ and $\mathrm{Zn}$ were extracted by $\mathrm{Di}$-acid mixer (HClO4:HNO3 at 2:1 ratio) method (Jackson, 1967). The evaluation was conducted at 45 DAl. Concentration of $P$ was determined by ascorbic acid blue color method from the standard curve prepared by potassium dihydrogen phosphate (Murphy and Riley, 1977), Concentration of Ca was determined by Flame-emission spectrophotometer from the standard curve of calcium carbonate (Black, 1955) and concentration of $\mathrm{Fe}, \mathrm{K}$ and $\mathrm{Zn}$ was determined Flameemission spectrophotometer from the standard curve of iron (iii) chloride, potassium chloride and zinc chloride respectively (Sahrawat, 1980; dos Santos Magalhaes, 2009). The determined concentration of these nutrient minerals was expressed as mg g-1 of fresh sample materials.

\section{Statistical analysis}

The experiment was carried out in a complete randomized design (CRD) with three replications. Data were subjected to analysis of variance (ANOVA) with Fisher's LSD test $(P<0.05)$ and significant differences of the means among treatments were analyzed using STATISTIX 10 software (Analytical software, USA). The standard deviation was calculated using Microsoft excel.

\section{Conclusion}

In conclusion, we found that the competence of BTH to mitigate citrus canker disease severity increased when applied in combination with PPN rather than individual application. The reduced DS may be linked with increased PAL activity, total phenolic compounds and soluble protein, whereas the role of accumulated nutrient minerals in leaf was only providing some extra facilities to PAL, TPC and SP to deter Xac activity. The above findings focus on the role of BTH and PPN in mitigating the citrus canker disease which 
provides information for the development of alternative disease management approach.

\section{Acknowledgements}

Ministry of Science and Technology, Government of the People's Republic of Bangladesh is acknowledged for financial support by providing National Science and Information and Communication Technology (NSICT) fellowship, 2014-15. The authors are grateful to Professor Nazneen Sultana for providing Xac bacterial strain and Assistant Professor Sayed Mohammad Mohsin for statistical analysis.

\section{Reference}

Benhamou N, Belanger RR (1998) Benzothiadiazolemediated induced resistance to Fusarium oxysporum $f$. sp.radicis-lycopersici in tomato. Plant Physiol. 118(4):12031212.

Biswas SK, Pandey NK, Rajik M (2012) Inductions of defense response in tomato against Fusarium wilt through inorganic chemicals as inducers. J Plant Pathol Microbiol. $3(4): 2-7$.

Black CA (1965) Methods of soil analysis, Part 2. Chemical and microbial properties. Madison Wis, Amer Soc Agron. P:771-512.

Boubakri H, Chong J, Poutaraud AC, Schmitt C, Bertsch A, Mliki JE, Masson I, Soustre-Gacougnoll (2013) Riboflavin (Vitamin B2) induces defence responses and resistance to Plasmopara viticola in grapevine. Eur J Plant Pathol. 1364:837-55.

Dong H, Beer SV (2000) Riboflavin induces disease resistance in plants by activating a novel signal transduction pathway. Phytopathology. 90:801-811.

Dordas C (2008) Role of nutrients in controlling plant diseases in sustainable agriculture. A review. Agron Sustain Dev. 28(1):33-46.

Dossantos Magalhaes IR, Oliveira SA, Araujo LM, Costa PRC, Araujo RI (2009) Determination of $\mathrm{Cu}, \mathrm{Fe}, \mathrm{Mn}$, and $\mathrm{Zn}$ in the leaves and tea of Arrabidaea chica (Humb. \& Bompl.). Verl Biol Trace Elem Res. 132(1-3):239-46.

Faoro F, Maffi D, Cantu D, Iriti M (2008) Chemical-induced resistance against powdery mildew in barley: the effects of chitosan and benzothiadiazole. BioControl. 53:387-40.

Friedrich L, Lawton K, Ruess W, Masner P, Specker N, Rella MG, Meier B, Dincher, Staub ST (1996) A benzothiadiazole derivative induces systemic acquired resistance in tobacco. Plant J. 10(1): 61-70. DOI: 10.1046/j.1365-313X.1996. 10010061.x.

Garcia-Brugger O, Lamotte E, Vandelle (2006) Early signaling events induced by elicitors of plant defenses. Mol PlantMicrobe Interact. 19(7):711-724.

Goodman MN, Kiraly Z, Wood KR (1986) Biochemistry and Physiology of Plant Disease. University of Missouri Press, Columbia.

Goszczynska T, Serfontein JJ (1998) Milk Tween Agar, a semiselective medium for isolation and differentiation of Pseudomonas syringae pv. syringae, Pseudomonas syringae pv. phaseolicola and Xanthomonas axonopodis pv. phaseoli. J Microbiol Meth. 32(1):65-72.
Graham JH, Leite RPJ (2004) Lack of control of citrus canker by induced systemic resistance compounds. Plant Dis. 88(7):745-750.

Gurr SJ, Rushton PJ (2005) Engineering plants with increased disease resistance: what are we going to express? Trends Biotechnol. 23:275-82.

Hasabi V, Askari H, Alavi SM, Zamanizadeh H (2014) Effect of amino acid application on induced resistance against citrus canker disease in lime plants. J Plant Prot Res. 54(2):145149.

Hukkanen AT, Kokko HI, Buchala AJ, McDougall GJ, Stewart D, Kärenlampi SO, Karjalainen RO (2007) Benzothiadiazole induces the accumulation of phenolics and improves resistance to powdery mildew in strawberries. J Agric Food Chem. 55(5):1862-70.

Jackson ML (1967) Soil Chemical Analysis. Prentice Hall of India Pvt. Ltd., New Delhi; p. 205.

Kovacs D, Rakacs M, Agoston B, Lenkey K, Semrad K, Schroeder R (2009) Janus chaperones: assistance of both RNA- and protein folding by ribosomal proteins. FEBS Lett. 583:88-92.

Li J, Wang N (2013) Foliar application of biofilm formationinhibiting compounds enhances control of citrus canker caused by Xanthomonas citri subsp. citri. Phytopathology. 104(2):134-142.

Li W, Xu YP, Zhang ZX, Cao WY, Li F (2012) Identification of genes required for nonhost resistance to Xanthomonas oryzae pv. oryzae reveals novel signaling components. PLOS ONE. 7(8).

Li Y, Yin Y, Bi Y, Wang D (2012) Effect of riboflavin on postharvest disease of asia pear and the possible mechanisms involved. Phytoparasitica. 40:261-268.

Liu F, Wei F, Wang L, Liu H, Zhu X, Liang Y (2010) Riboflavin activates defense responses in tobacco and induces resistance against Phytophthora parasitica and Ralstonia solanacearum. Physiol Mol Plant Path. 74(5-6):330-33.

Lowry OH, Rosebrough NJ, Farr AL, Randall RJ (1951) Protein measurement with the folin phenol reagent. J Biol Chem. 193:265-275. PMID:14907713

Maddox CE, Laur LM, Tian L (2010) Antibacterial activity of phenolic compounds against the phytopathogen Xylella fastidiosa. Curr Microbiol. 60(1):53-58.

Marschner H (1995) Mineral Nutrition of Higher Plants, 2nd ed., Academic Press, London, p. 889.

McKenzie HA, Wallace HS (1954) The Kjeldahl determination of nitrogen: A critical study of digestion conditionsTemperature, Catalyst, and Oxidizing agent. Aust J Chem. 7(1):55- 70 .

Murphy J, Riley JR (1977) A modified single solution method for the determination of phosphate in natural waters. Anal Chem. 27:1-36.

Nagaraj S, Senthil-Kumar M, Ramu VS, Wang K, Mysore KS (2016) Plant ribosomal proteins, RPL12 and RPL19, play a role in nonhost disease resistance against bacterial pathogens. Front Plant Sci. 6:1192.

Nayem SA, Chowdhury MSM, Aminuzzaman FM, Hossain B, Ali $S$ (2017) Phytohormone-induced resistance against Xanthomonas axonopodis PV. citri in Citrus aurantifolia. Am J Plant Sci. 8:1135-1147.

Peixoto de Oliveira, ML, Silva CCL, Abe VY, Costa MGC, Cernadas RA, Benedetti CE (2013) Increased resistance against citrus canker mediated by a citrus mitogen- 
activated protein kinase. Mol Plant-Microbe Interact. 26(10):1190-1199.

Rai VR, Mamatha T (2005) Seedling diseases of some important forest tree species and their management. In: Working paper of the Finish Forest Research Institute, $p$. 11

Sahrawat KL (1980) A rapid non-digestion method for determination of potassium in plant tissue. Commun. Soil Sci Plant Anal. 11(7):753-757.

Sayed MKA (2015) Selection for resistant varieties of okra to yellow vein clearing mosaic virus and its management through peak performance nutrients, imidacloprid and sobicron. MS thesis. Sher-E-Bangla Agricultural University.

Scarponi L, Buonaurio R, Martinetti L (2001) Persistance and translocation of a benzothiadiazole derivative in tomato plants in relation to systemic acquired resistance against Pseudomonsas syringae pv. Tomato. Pest Manag Sci. 57:262-268.

Schaad NW (1992) Xanthomonas. In: Laboratory guide for identification of plant pathogenic bacteria, 2nd Edition, International Book Distributing Co., Lucknow, 165.

Stadnik MJ, Buchenauer H (2000) Inhibition of phenylalanine ammonia-lyase suppresses the resistance induced by benzothiadiazole in wheat to Blumeria graminis f.sp.tritici. Physiol Molr Plant Path. 57:25-34.
Taheri P, Hofte M (2007) Riboflavin-induced resistance against rice sheath blight functions through the potentiation of lignin formation and jasmonic acid signaling pathway. Commun Agric Appl Bio Sci. 12:309-313. PMID: 18399457.

Wang Y, Liu JH (2012) Exogenous treatment with salicylic acid attenuates occurrence of citrus canker in susceptible navel orange (Citrus sinensis Osbeck). J Plant Physiol. 169(12):1143-4.

Yan Z, Reddy MS, Yyu CM, Mcinroy JA, Wilson M, Kloepper JW (2002) Induced systemic protection against tomato late blight by plant growth-promoting rhizobacteria. Phytopathology. 92: 1329-1333.

Yao H, Tian S (2005) Effects of pre- and post-harvest application of salicylic acid or methyl jasmonate on inducing disease resistance of sweet cherry fruit in storage. Postharvest Biol Technol. 35: 253-262.

Zhua YJ, Qiub X, Moorec PH, Borthd W, Hud J, Ferreirad S, Albertc HH (2003) Systemic acquired resistance induced by BTH in papaya. Physiol Mol Plant Pathol. 63:237-248. 